\title{
A new protocol for the synthesis of 4,7,12,15-tetrachloro[2.2]paracyclophane
}

\author{
Donghui Pan, Yanbin Wang and Guomin Xiao*
}

\author{
Full Research Paper \\ Address: \\ School of Chemistry and Chemical Engineering, Southeast University, \\ 2 Dongnan Daxue Road, Nanjing, Jiangsu, 211189, P. R. China \\ Email: \\ Guomin Xiao* - xiaogm426@gmail.com \\ * Corresponding author \\ Keywords: \\ bromination; dimerization; $\mathrm{H}_{2} \mathrm{O}_{2}-\mathrm{HBr}$ system; paracyclophane; \\ polymerization inhibitor
}

\author{
Beilstein J. Org. Chem. 2016, 12, 2443-2449. \\ doi:10.3762/bjoc. 12.237 \\ Received: 23 August 2016 \\ Accepted: 02 November 2016 \\ Published: 17 November 2016 \\ This article is part of the Thematic Series "Green chemistry". \\ Guest Editor: L. Vaccaro \\ (c) 2016 Pan et al.; licensee Beilstein-Institut. \\ License and terms: see end of document.
}

\begin{abstract}
We report a green and convenient protocol to prepare 4,7,12,15-tetrachloro[2.2]paracyclophane, the precursor of parylene $\mathrm{D}$, from 2,5-dichloro- $p$-xylene. In the first bromination step, with $\mathrm{H}_{2} \mathrm{O}_{2}-\mathrm{HBr}$ as a bromide source, this procedure becomes organic-wastefree and organic-solvent-free and can appropriately replace the existing bromination methods. The Winberg elimination-dimerization step, using aqueous sodium hydroxide solution instead of silver oxide for anion exchange, results in a significant improvement in product yield. Furthermore, four substituted [2.2]paracyclophanes were also prepared in this convenient way.
\end{abstract}

\section{Introduction}

Parylene films (Figure 1) are desired uniform coating materials that are widely used in microelectronic engineering, automotive and medical industries, owing to their low dielectricity, high thermal and oxidative stability, and chemical inertness [1-4]. Parylene N was firstly commercialized, and its precursor [2.2]paracyclophane (Figure 2) was typically produced by Hofmann elimination $[5,6]$. As reported, the uniform coating properties of parylene films were improved by introducing halogen atoms to the structure of the parent [2.2]paracyclophane [7]. Therefore, the two chloride atoms on the benzene ring make parylene $\mathrm{D}$ superior to parylene $\mathrm{N}$ and parylene $\mathrm{C}$. There are some creative strategies for the synthesis of 4,7,12,15-tetrachloro[2.2] paracyclophane (Figure 2), the precur- sor of parylene D [8]. Theoretically, direct chlorination of [2.2]paracyclophane is an ideal route to prepare tetrachloroparacyclophane, but a pure polysubstituted product is difficult to obtain by electrophilic substitution without repeated crystallization or chromatographic purification [9]. Thus, we report an improved synthesis method using the Winberg dimerization of 2,5-dichloro-(4-methylbenzyl)trimethylammonium hydroxide without tedious purification.

The important chemical 1-(bromomethyl)-2,5-dichloro-4methylbenzene is an intermediate in the preparation of 2,5dichloro-(4-methylbenzyl)trimethylammonium hydroxide. During our investigation of the synthesis of 4,7,12,15-tetra- 


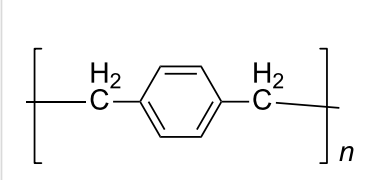

parylene $\mathrm{N}$

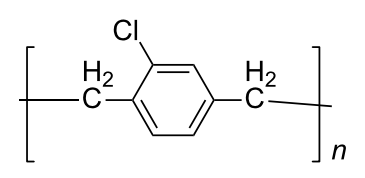

parylene C

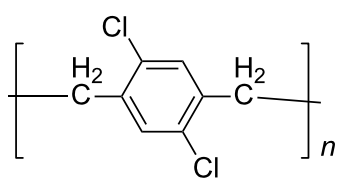

parylene D

Figure 1: Chemical structures of parylene $\mathrm{N}$, parylene $\mathrm{C}$, and parylene D.
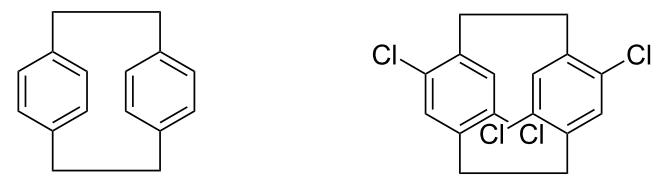

[2.2]paracyclophane

4,7,12,15-tetrachloro[2.2]paraclophane

Figure 2: Chemical structures of [2.2]paracyclophane and 4,7,12,15tetrachloro[2.2]paracyclophane.

chloro[2.2]paracyclophane, we also adopted an improved bromination process to prepare 1-(bromomethyl)-2,5-dichloro-4methylbenzene. Traditionally, there are several disadvantages when molecular bromine is used as a brominating reagent, such as toxicity, inconvenient handling and high reactivity, which lead to unsatisfactory results in the bromination process [1012]. In addition, the release of corrosive $\mathrm{HBr}$ as a byproduct and the use of organic solvents make this protocol less environmentally friendly [13]. The use of other brominating agents, such as $\mathrm{N}$-bromosuccinimide (NBS) and pyridinium tribromides, also has the drawbacks such as low atom efficiency and the requirement of reagent residue elimination [14]. In contrast to traditional brominating reagents, the $\mathrm{H}_{2} \mathrm{O}_{2}-\mathrm{HBr}$ system, which generates active bromine in situ, is a convenient and green brominating agent [15]. Furthermore, the use of the $\mathrm{H}_{2} \mathrm{O}_{2}-\mathrm{HBr}$ couple improves the selectivity and allows for the complete utilization of bromine atoms, thus increasing the atom economy [16]. These advantages prompted us to develop a novel method to prepare 1-(bromomethyl)-2,5-dichloro-4-methylbenzene and 4,7,12,15-tetrachloro[2.2]paracyclophane in a convenient and green way.

\section{Results and Discussion}

We initially planned to optimize the reaction conditions for the bromination of the benzylic position of 2,5-dichloro- $p$-xylene
(1) by using the $\mathrm{H}_{2} \mathrm{O}_{2}-\mathrm{HBr}$ system, and investigated various factors, including the activation mode, the reagent stoichiometry, the solvent, and the reaction temperature (Table 1).

The bromination reaction activated by heating in the dark produced a $62.9 \%$ yield of the monobrominated product 1-(bromomethyl)-2,5-dichloro-4-methylbenzene (2a) accompanied by a small amount of 1,4-bis(bromomethyl)-2,5-dichlorobenzene (2b) (Table 1, entry 2). Next, a radical reaction was induced by adding $3 \mathrm{~mol} \%$ of radical initiator (DBP or AMPA) and proceeded at $75{ }^{\circ} \mathrm{C}$ for $4 \mathrm{~h}$ (Table 1 , entries 3 and 4 ). Though the yields in both processes increased, the selectivity of 2a decreased due to the formation of some excessive brominated byproducts. Then, we tried visible light as activator of the racial process. Interestingly, the yield and the selectivity of $\mathbf{2 a}$ increased when a $40 \mathrm{~W}$ incandescent light bulb was used at $25^{\circ} \mathrm{C}$ for $6 \mathrm{~h}$ (Table 1 , entry 5 ) compared to other activation modes.

To make the chemical process green, we designed a bromination process with water as the reaction medium rather than organic solvents. Despite the low solubility of the organic substrates, the yields of $\mathbf{2 a}$ were improved without significant formation of byproducts (Table 1, entries 5 and 6). Furthermore, it was convenient to separate the organic product from the reaction mixtures. In small-scale experiments, a simple extraction with an appropriate organic solvent was efficient to obtain the product. However, in large-scale bromination processes, a clear phase separation occurred, so the product could be obtained by drying the organic phase after separation from the aqueous phase.

Considering the $\mathrm{H}_{2} \mathrm{O}_{2}$ decomposition in the presence of $\mathrm{HBr}$ and $\mathrm{Br}_{2}$ in the reaction, the effect of the amount of $\mathrm{H}_{2} \mathrm{O}_{2}$ was investigated. Actually, the yields of $\mathbf{2 a}$ increased to $73.1 \%$ and $80.4 \%$ when 1.5 and 2.0 equiv of $\mathrm{H}_{2} \mathrm{O}_{2}$ were used (Table 1, entries 7 and 8), respectively, in the bromination process. Similarly, when the amount of $\mathrm{HBr}$ increased to 1.1 equiv, the yield of 2a was maximized (Table 1, entry 9). However, a large amount of $\mathbf{2} \mathbf{b}$ was found when excessive $\mathrm{HBr}$ (1.5 equiv) was used, which decreased the selectivity of this bromination protocol (Table 1, entry 10).

The effect of reagent addition modes on the bromination yields was also studied. The results showed that gradual addition of $\mathrm{H}_{2} \mathrm{O}_{2}$ (method $\mathrm{B}$ ) improved the yield of the main product 2a in contrast to a one-time addition of $\mathrm{H}_{2} \mathrm{O}_{2}$ (method A). This may be due to a significant decrease of $\mathrm{H}_{2} \mathrm{O}_{2}$ decomposition during the slow addition process. In addition, the $\mathrm{Br}_{2}$ generated in situ was reduced by stepwise addition of $\mathrm{H}_{2} \mathrm{O}_{2}$, which would improve the selectivity of $\mathbf{2 a}$ by preventing the side reactions. 
Table 1: Bromination of 2,5-dichloro-p-xylene (1) with $\mathrm{H}_{2} \mathrm{O}_{2}-\mathrm{HBr}$.<smiles>Cc1cc(Cl)c(C)cc1Cl</smiles>

\begin{tabular}{|c|c|c|c|c|c|c|c|}
\hline \multirow[t]{2}{*}{ Entry } & \multirow[t]{2}{*}{$1 / \mathrm{H}_{2} \mathrm{O}_{2} / \mathrm{HBr}$} & \multirow[t]{2}{*}{ Mode of initiation $^{a}$} & \multirow[t]{2}{*}{ Solvent } & \multirow[t]{2}{*}{ Method $^{b}$} & \multirow[t]{2}{*}{ Temp. $\left({ }^{\circ} \mathrm{C}\right)$} & \multicolumn{2}{|c|}{ Yield $^{\mathrm{C}}(\%)$} \\
\hline & & & & & & $2 a$ & $2 b$ \\
\hline 1 & $1: 1: 1$ & dark & $\mathrm{CCl}_{4}$ & $A$ & 25 & 22.8 & - \\
\hline 2 & $1: 1: 1$ & dark & $\mathrm{CCl}_{4}$ & $A$ & 75 & 62.9 & 4.2 \\
\hline 3 & $1: 1: 1$ & $3 \%$ DBP & $\mathrm{CCl}_{4}$ & $A$ & 75 & 65.8 & 8.1 \\
\hline 4 & $1: 1: 1$ & $3 \%$ AMPA & $\mathrm{CCl}_{4}$ & A & 75 & 62.3 & 7.8 \\
\hline 5 & 1:1:1 & incandescent light & $\mathrm{CCl}_{4}$ & A & 25 & 70.2 & 3.5 \\
\hline 6 & $1: 1: 1$ & incandescent light & $\mathrm{H}_{2} \mathrm{O}$ & $A$ & 25 & 68.8 & 2.5 \\
\hline 7 & $1: 1.5: 1$ & incandescent light & $\mathrm{H}_{2} \mathrm{O}$ & A & 25 & 73.1 & 4.6 \\
\hline 8 & $1: 2: 1$ & incandescent light & $\mathrm{H}_{2} \mathrm{O}$ & A & 25 & 80.4 & 4.2 \\
\hline 9 & $1: 2: 1.1$ & incandescent light & $\mathrm{H}_{2} \mathrm{O}$ & $A$ & 25 & 85.1 & 3.5 \\
\hline 10 & $1: 2: 1.5$ & incandescent light & $\mathrm{H}_{2} \mathrm{O}$ & A & 25 & 82.7 & 10.1 \\
\hline 11 & $1: 2: 1.1$ & incandescent light & $\mathrm{H}_{2} \mathrm{O}$ & $\mathrm{B}$ & 25 & 89.9 & 1.2 \\
\hline 12 & $1: 2: 1.1$ & incandescent light & $\mathrm{H}_{2} \mathrm{O}$ & B & 80 & 65.1 & 28.2 \\
\hline
\end{tabular}

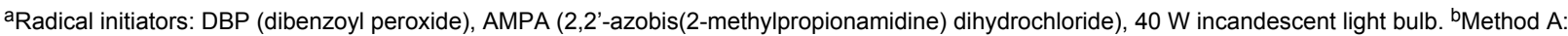
$\mathrm{H}_{2} \mathrm{O}_{2}$ and $\mathrm{HBr}$ were added in one portion; Method $\mathrm{B}: \mathrm{H}_{2} \mathrm{O}_{2}$ was added gradually (1 equiv per $2.5 \mathrm{~h}$ ). ${ }^{c}$ Yields were determined by ${ }^{1} \mathrm{H}$ NMR spectroscopy and were based on starting compound 1 .

Next, the bromination of other para-xylene derivatives under optimized conditions (see Table 1, entry 11) were investigated to examine the versatility of the protocol. As can be seen in Table 2, para-xylene (3), 2-chloro-1,4-dimethylbenzene (5) and 2-bromo-1,4-dimethylbenzene (7) were converted to the corresponding benzyl bromides in high yields with a small amount of dibrominated byproducts. However, in the case of 1-nitro-2,5dimethylbenzene (9), a lower yield of benzyl brominated product was obtained. This could be explained by the deactivating effect of the nitro group [16]. Therefore, a $100 \mathrm{~W}$ high pressure mercury lamp ('solar' light) was used to increase the formation of bromide radical in the repeated bromination experiment of 9. On this occasion the yield of the monobrominated product 10a was high, and this was in agreement with the literature [16].

Five brominated products were obtained through the above bromination protocol, and were used to synthesize substituted (4-methylbenzyl)trimethylammonium bromides in diethyl ether at $0{ }^{\circ} \mathrm{C}$ with quantitative yields [17] (Scheme 1).

Then, we used 2,5-dichloro-(4-methylbenzyl)trimethylammonium bromide (11) as starting material to prepare tetrachloro[2.2]paracyclophane in an aqueous sodium hydroxide solution according to Winberg's method $[18,19]$. The interme-
Table 2: Visible-light induced free-radical bromination of substituted p-xylenes with $\mathrm{H}_{2} \mathrm{O}_{2}-\mathrm{HBr}$.

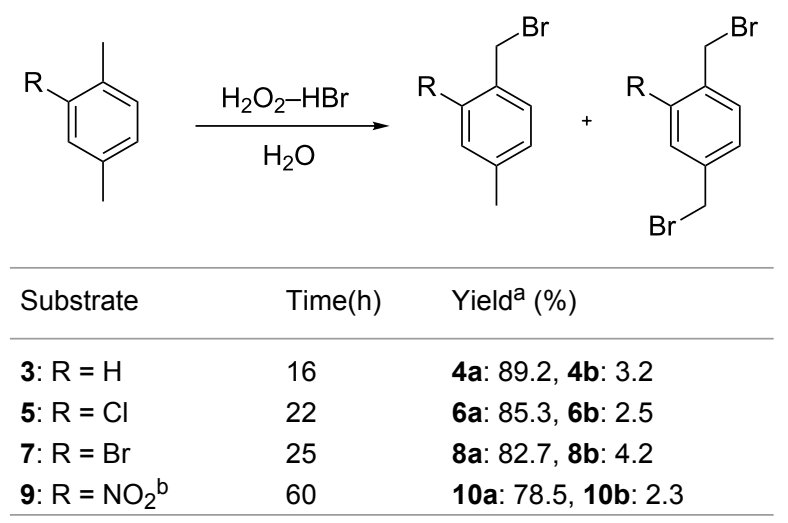

aYields were determined by ${ }^{1} \mathrm{H}$ NMR spectroscopy and were based on starting compounds. ${ }^{\mathrm{b}}$ The reaction mixture was irradiated with a $100 \mathrm{~W}$ high pressure mercury lamp.

diate 2,5-dichloro-(4-methylbenzyl)trimethylammonium hydroxide was formed and then decomposed in boiling toluene, resulting in a small amount of a dimer product $\mathbf{1 6}$ and a quantity of polymer byproduct (Table 3, entry 1 ). After the reaction, the polymer byproduct was removed by filtration, and the dimer product was obtained by concentrating the filtrate under 


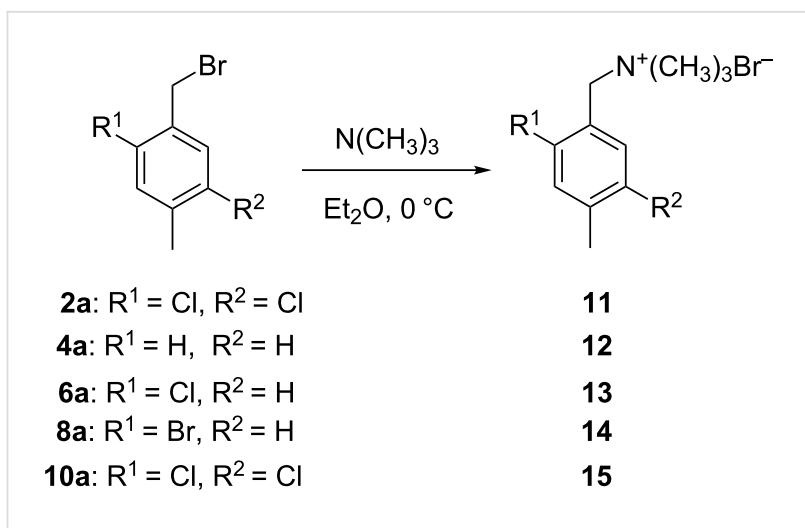

Scheme 1: Synthesis of substituted (4-methylbenzyl)trimethylammonium bromides from substituted (4-methylbenzyl)bromides.

reduced pressure. Thus, a chromatographic purification was not necessary in the improved dimerization protocol.

To suppress the polymerization and to improve the yield of the dimer product, we attempted the addition of a polymerization inhibitor. As expected, the addition of $3 \mathrm{~mol} \%$ phenothiazine significantly improved the yield of $\mathbf{1 6}$ to $25 \%$ (Table 3 , entry 2 ). The addition of 2-chlorophenothiazine increased the yield to $35 \%$ (Table 3, entry 3), which was about three times than that without any inhibitor. In addition, the $35 \%$ yield of dimer product was about two times the yield (20\%) when the protocol with silver oxide for anion exchange was used [17], and it was comparable to the commercial synthetic protocol with $36.5 \%$ yield [20]. Although two isomers from the dimerization reaction could be formed, only the 4,7,12,15-tetrachloro isomer was obtained. The structure of the product was confirmed by ${ }^{1} \mathrm{H}$ and ${ }^{13} \mathrm{C}$ NMR spectral analysis, and the data matched well with the reported results [17]. Furthermore, the ${ }^{1} \mathrm{H}$ NMR spectra of the $\mathrm{CH}_{2} \mathrm{CH}_{2}$ bridge in the paracyclophane structure was consistent with the data reported in the literature, which also identified the 4,7,12,15-tetrachloro isomer [21].
Then, four substituted [2.2]paracyclophanes were synthesized from substituted (4-methylbenzyl)trimethylammonium bromides in aqueous sodium hydroxide solution in the presence of a polymerization inhibitor (Table 4). It was found that the yields of dimer products were improved dramatically compared to the results obtained with silver oxide used for anion exchange reported by Chow [17]. We speculated that the replacement of silver oxide by aqueous sodium hydroxide solution might promote the formation of substituted (4-methylbenzyl)trimethylammonium hydroxide, but we are unable to provide any conclusive evidence at presence. For the dimerization of 12, the [2.2]paracyclophane (17) was obtained in 33\% yield, and its structure was confirmed by NMR spectroscopy and elemental analysis. Similarly, dimerization of $\mathbf{1 3}, \mathbf{1 4}$, and $\mathbf{1 5}$ resulted in regiospecific 4,16-disubstituted [2.2] paracyclophanes 18, 19, and 20, respectively, in about 35\% yield (Table 4, entries 2, 3 and 4). The structures of the synthesized 4,16-disubstituted [2.2]paracyclophanes were also consistent with their NMR spectral data.

\section{Conclusion}

A convenient protocol was reported to synthesize 4,7,12,15tetrachloro[2.2]paracyclophane. In the first bromination step, 1-(bromomethyl)-2,5-dichloro-4-methylbenzene was synthesized with high yield and selectivity from 2,5-dichloro- $p$ xylene by using a $\mathrm{H}_{2} \mathrm{O}_{2}-\mathrm{HBr}$ couple in water. The use of $\mathrm{H}_{2} \mathrm{O}_{2}-\mathrm{HBr}$ as a bromide source made this procedure organicwaste-free, organic-solvent-free and an appropriate replacement of the existing bromination methods. In the Winberg elimination-dimerization step, $35 \%$ yield of 4,7,12,15-tetrachloro[2.2]paracyclophane was obtained from 2,5-dichloro-(4methylbenzyl)trimethylammonium bromide and aqueous sodium hydroxide solution in the presence of a polymerization inhibitor, which was about two folds than that used silver oxide as anion exchange. Moreover, four substituted [2.2]paracyclophanes were prepared in this convenient way.

Table 3: Synthesis of 4,7,12,15-tetrachloro[2.2]paracyclophane 16 from 11
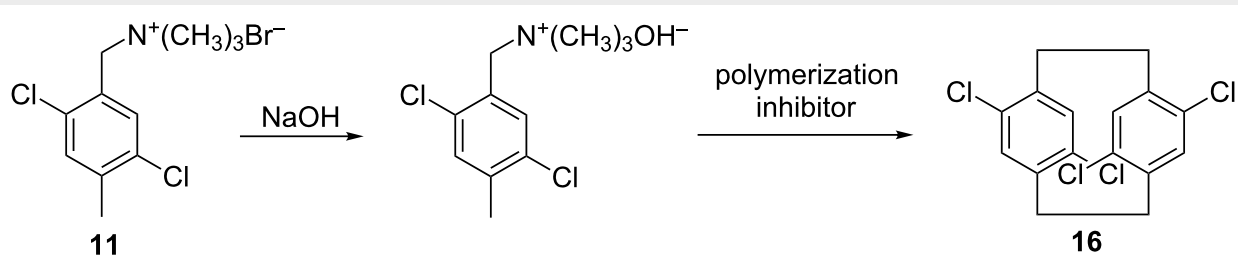

\begin{tabular}{llr}
\hline Entry & Polymerization inhibitor & Yield \\
\hline 1 & - & 12 \\
2 & phenothiazine & 25 \\
3 & 2-chlorophenothiazine & 35 \\
\hline
\end{tabular}

aYields of products were based on compound 11 
Table 4: Synthesis of substituted [2.2]paracyclophanes from substituted (4-methylbenzyl)trimethylammonium bromides.

Entry

Starting material

Product

Yield $^{a}(\%)$

1<smiles>Cc1ccc(C[NH+](C)C(C)(Br)Br)cc1</smiles>

12

2<smiles>Cc1ccc(C[NH+](C)C(C)(Br)Br)c(Cl)c1</smiles>

13

3

4<smiles>Cc1ccc(C[N+](C)(C)Br)c(Br)c1</smiles>

14

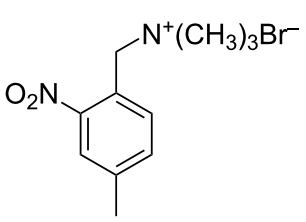

15

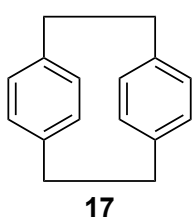

17

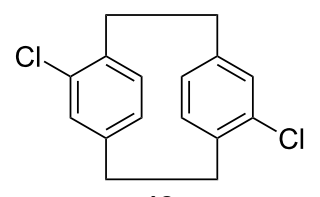

18

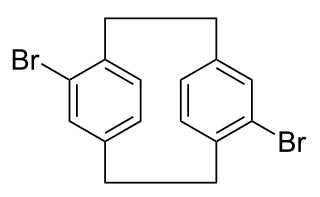

19

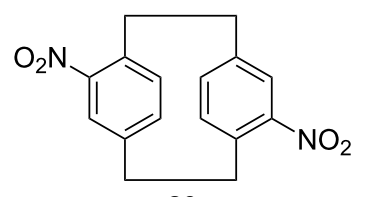

20

aln the presence of 2-chlorophenothiazine. The numbers in parenthesis are the yields in the presence of phenothiazine.

\section{Experimental}

\section{General}

2,5-Dichloro- $p$-xylene, para-xylene, 2-chloro-1,4-dimethylbenzene, 2-bromo-1,4-dimethylbenzene and 1-nitro-2,5-dimethylbenzene were purchased from commercial suppliers. All chemicals were used as received without further purification. ${ }^{1} \mathrm{H}$ NMR spectra were recorded in $\mathrm{CDCl}_{3}$ using an AVANCE III 400WB spectrometer. IR spectra were recorded on a Nicolet AVATAR 5700 FTIR spectrophotometer in the range of $4000-400 \mathrm{~cm}^{-1}$ using $\mathrm{KBr}$ pellets. Melting points were determined using a Beijing TaiKe X-4 melting point apparatus and were uncorrected. Mass spectra were obtained using an Agilent 1260-6224 spectrometer with electron impact ionization (EI, $70 \mathrm{eV}$ ). Elemental analyses were recorded on an Elementar vario MICRO cube.

\section{Typical reaction procedure for visible-light induced bromination with the $\mathrm{H}_{2} \mathrm{O}_{2}-\mathrm{HBr}$ system}

Analogous as described in [16], substituted $p$-xylene (1.0 mmol) was added to $2.0 \mathrm{~mL}$ solution $\left(\mathrm{CCl}_{4}\right.$ or water) of $2.0 \mathrm{mmol}$ of
$\mathrm{H}_{2} \mathrm{O}_{2}\left(0.23 \mathrm{~g}, 30 \% \mathrm{H}_{2} \mathrm{O}_{2}\right.$ aqueous $)$ and $1.1 \mathrm{mmol}$ of $\mathrm{HBr}$ (0.22 g, 30\% HBr aqueous). The mixture was stirred at $300 \mathrm{rpm}$ at appropriate temperature under irradiation from a $40 \mathrm{~W}$ incandescent light bulb. At the end of the bromination reaction (6-20 h), the mixture was transferred into a separating funnel and $4 \mathrm{~mL}$ of $0.005 \mathrm{M} \mathrm{NaHSO}_{3}$ was added. The crude product was extracted using $3 \times 5 \mathrm{~mL} \mathrm{CH}_{2} \mathrm{Cl}_{2}$ and the combined organic phase was dried over $\mathrm{MgSO}_{4}$. Then the solvent was evaporated under reduced pressure and the crude mixture was analyzed by ${ }^{1} \mathrm{H}$ NMR spectroscopy. Lastly the products were separated by column chromatography $\left(\mathrm{SiO}_{2}\right.$, hexane/EtOAc) and identified by comparison with literature data.

2a: colorless oil. ${ }^{1} \mathrm{H}$ NMR $\left(\mathrm{CDCl}_{3}\right) \delta 2.24\left(\mathrm{~s}, 3 \mathrm{H}, \mathrm{ArCH}_{3}\right), 5.12$ (s, 2H, $\left.\mathrm{ArCH}_{2}\right), 7.29$ (s, 1H, ArH), 7.33 (s, 1H, ArH); EIMS $m / z: 254,175,173,102$.

4a: colorless oil. ${ }^{1} \mathrm{H}$ NMR $\left(\mathrm{CDCl}_{3}\right) \delta 2.19\left(\mathrm{~s}, 3 \mathrm{H}, \mathrm{ArCH}_{3}\right), 4.66$ (s, 2H, $\mathrm{ArCH}_{2}$ ), 7.07-7.11 (m, 2H, ArH), 7.25-7.31 (m, 1H, ArH); anal. calcd for $\mathrm{C}_{8} \mathrm{H}_{9} \mathrm{Br}$ (185.06): C, 51.92; H, 4.90; found: C, 51.81; H, 4.96. 
6a: colorless oil. ${ }^{1} \mathrm{H}$ NMR $\left(\mathrm{CDCl}_{3}\right) \delta 2.31\left(\mathrm{~s}, 3 \mathrm{H}, \mathrm{ArCH}_{3}\right), 4.95$ (s, 2H, $\left.\mathrm{ArCH}_{2}\right), 6.96-6.98(\mathrm{~m}, 1 \mathrm{H}, \mathrm{ArH}), 6.99-7.24(\mathrm{~m}, 1 \mathrm{H}$, ArH), 7.26-7.37 (m, 1H, ArH); anal. calcd for $\mathrm{C}_{8} \mathrm{H}_{8} \mathrm{BrCl}$ (219.51): C, 43.77; H, 3.67; Cl, 16.15; found: C, 43.68; H, 3.72; $\mathrm{Cl}, 16.06$.

8a: mp 53-55 ${ }^{\circ} \mathrm{C} ;{ }^{1} \mathrm{H}$ NMR $\left(\mathrm{CDCl}_{3}\right) \delta 2.31$ (s, 3H, $\left.\mathrm{ArCH}_{3}\right)$, $4.93\left(\mathrm{~s}, 2 \mathrm{H}, \mathrm{ArCH}_{2}\right), 7.02-7.54$ (m, 3H, ArH); anal. calcd for $\mathrm{C}_{8} \mathrm{H}_{8} \mathrm{BrCl}$ (219.51): $\mathrm{C}, 43.77 ; \mathrm{H}, 3.67 ; \mathrm{Cl}, 16.15$; found: $\mathrm{C}$, 43.68; H, 3.72; Cl, 16.06 .

10a: mp 72-74 ${ }^{\circ} \mathrm{C} ;{ }^{1} \mathrm{H}$ NMR $\left(\mathrm{CDCl}_{3}\right) \delta 2.41$ (s, 3H, $\left.\mathrm{ArCH}_{3}\right)$, 4.95 (s, 2H, $\left.\mathrm{ArCH}_{2}\right), 6.96-7.37$ (m, 3H, ArH); anal. calcd for $\mathrm{C}_{8} \mathrm{H}_{8} \mathrm{BrNO}_{2}$ (230.06): C, 41.77; H, 3.51; N, 6.09; found: $\mathrm{C}$, 41.68; H, 3.57; N, 6.12 .

\section{Typical reaction procedure for the prepara- tion of substituted (4-methylbenzyl)trimethyl- ammonium bromides}

Substituted 4-methylbenzyl bromide $(5.0 \mathrm{mmol})$ was added to $50.0 \mathrm{~mL} \mathrm{Et}_{2} \mathrm{O}$ solution in a $100 \mathrm{~mL}$ three-necked flask. The mixture was cooled at $0{ }^{\circ} \mathrm{C}$ and was stirred at $300 \mathrm{rpm}$. $\mathrm{Me}_{3} \mathrm{~N}$ was generated by heating an aqueous $\mathrm{Me}_{3} \mathrm{~N}$ solution $(40 \% \mathrm{w} / \mathrm{w}$, $15 \mathrm{~mL}$ ) and passed into the flask for $4 \mathrm{~h}$. The product was precipitated as a white solid. Then the mixture was stirred at room temperature overnight and the quaternary ammonium salt was obtained on a Büchner funnel and dried in a vacuum oven at $80{ }^{\circ} \mathrm{C}$ for $24 \mathrm{~h}$.

11: highly hygroscopic solid. IR (KBr) $v / \mathrm{cm}^{-1}$ : 3004, 1635, 1617, 1477, 1375, 1190, 980.

12: highly hygroscopic solid. IR (KBr) v/ $\mathrm{cm}^{-1}: 2989,1521$, 1483, 1382, 1125, 910, 805, 722.

13: highly hygroscopic solid. IR (KBr) v/cm ${ }^{-1}$ : 2968, 2935, 1632, 1452, 1371, 1154, 725, 672 .

14: highly hygroscopic solid. IR (KBr) v/ $\mathrm{cm}^{-1}: 3009,2946$, $1642,1458,1381,1205,653$.

15: highly hygroscopic solid. IR (KBr) v/ $\mathrm{cm}^{-1}: 2979,1621$, $1550,1508,1472,1376,1345,1135,663$.

\section{Typical reaction procedure for the synthesis of substituted tetrachloro[2.2]paracyclo- phanes}

In a $100 \mathrm{~mL}$ three-necked flask equipped with a stirrer and a Dean-Stark water separator attached to a reflux condenser was placed $15 \mathrm{~mL}$ aqueous sodium hydroxide solution $(40 \% \mathrm{w} / \mathrm{w})$ and $45 \mathrm{~mL}$ toluene. With vigorous stirring, a solution of benzyltrimethylammonium bromides $(50 \mathrm{mmol})$, dissolved in $5 \mathrm{~mL}$ water, was added dropwise in $30 \mathrm{~min}$. The inhibitor $(0.15 \mathrm{mmol})$ was then added to the solution and the mixture was heated under reflux for $4 \mathrm{~h}$. After all water had been separated, a pale yellow solid polymer began to precipitate. When the evolution of $\mathrm{Me}_{3} \mathrm{~N}$ was finished, the reaction system was heated and stirred for another $1 \mathrm{~h}$. The mixture was cooled and the solid was filtrated and washed with toluene $(5 \mathrm{~mL} \times 3)$. The filtrates were combined and evaporated under vacuum to give a solid product which was further washed with hexane $(5 \mathrm{~mL} \times 3)$.

16: white solid, $\mathrm{mp}>280{ }^{\circ} \mathrm{C}(\mathrm{dec}) ;{ }^{1} \mathrm{H} \mathrm{NMR}\left(\mathrm{CDCl}_{3}\right) \delta 2.91$ (m, 2H, $\left.\mathrm{ArCH}_{2}\right), 3.26\left(\mathrm{~m}, 2 \mathrm{H}, \mathrm{ArCH}_{2}\right), 6.95$ (s, 2H, ArH); ${ }^{13} \mathrm{C} \mathrm{NMR}\left(\mathrm{CDCl}_{3}\right) \delta 30.8,77.0,131.8,133.9,138.6$; anal. calcd for $\mathrm{C}_{16} \mathrm{H}_{12} \mathrm{Cl}_{4}$ (346.07): C, 55.53; H, 3.50; Cl, 40.97; found: $\mathrm{C}$, $55.47 ; \mathrm{H}, 3.62 ; \mathrm{Cl}, 40.89$.

17: white solid, $\mathrm{mp} 281-283{ }^{\circ} \mathrm{C} ;{ }^{1} \mathrm{H}$ NMR $\left(\mathrm{CDCl}_{3}\right) \delta 3.09$ (s, $\left.8 \mathrm{H}, \mathrm{ArCH}_{2}\right), 6.50(\mathrm{~s}, 8 \mathrm{H}, \mathrm{ArH})$; anal. calcd for $\mathrm{C}_{16} \mathrm{H}_{16}$ (208.30): C, 92.26; H, 7.74; found: C, 92.15; H, 7.82.

18: white solid, mp $163-165{ }^{\circ} \mathrm{C} ;{ }^{1} \mathrm{H}$ NMR $\left(\mathrm{CDCl}_{3}\right) \delta 2.85-2.97$ (m, 4H, $\left.\mathrm{ArCH}_{2}\right), 3.03-3.37$ (m, 4H, $\left.\mathrm{ArCH}_{2}\right), 6.92-7.54(\mathrm{~m}, 6 \mathrm{H}$, ArH). anal. calcd for $\mathrm{C}_{16} \mathrm{H}_{14} \mathrm{Cl}_{2}$ (277.19): $\mathrm{C}, 69.33 ; \mathrm{H}, 5.09 ; \mathrm{Cl}$, 25.58; found: C, 69.27; H, 5.05; Cl, 25.65.

19: white solid, mp $238-240{ }^{\circ} \mathrm{C} ;{ }^{1} \mathrm{H}$ NMR $\left(\mathrm{CDCl}_{3}\right) \delta 2.86-3.12$ (m, 4H, $\mathrm{ArCH}_{2}$ ), 3.15-3.34 (4H, m, $\left.\mathrm{ArCH}_{2}\right), 6.43-7.15$ (m, 6H, ArH); anal. calcd for $\mathrm{C}_{16} \mathrm{H}_{14} \mathrm{Br}_{2}$ (366.10): C, 52.49; H, 3.85; found: C, 52.38; H, 3.82.

20: ${ }^{1} \mathrm{H}$ NMR $\left(\mathrm{CDCl}_{3}\right) \delta 2.81-3.07\left(\mathrm{~m}, 4 \mathrm{H}, \mathrm{ArCH}_{2}\right), 3.27-3.35$ $\left(\mathrm{m}, 4 \mathrm{H}, \mathrm{ArCH}_{2}\right), 7.25-8.23(\mathrm{~m}, 6 \mathrm{H}, \mathrm{ArH})$; anal. calcd for $\mathrm{C}_{16} \mathrm{H}_{14} \mathrm{~N}_{2} \mathrm{O}_{4}$ (298.30): C, 64.42; H, 4.73; N, 9.39; found: $\mathrm{C}$, 64.32; H, 4.75; N, 9.45 .

\section{Supporting Information}

\section{Supporting Information File 1}

Copies of MS, ${ }^{1} \mathrm{H}$ and ${ }^{13} \mathrm{C}$ NMR spectra of the synthesized compounds.

[http://www.beilstein-journals.org/bjoc/content/ supplementary/1860-5397-12-237-S1.pdf]

\section{Acknowledgements}

This work was financially supported by the National Natural Science Foundation of China (No. 21276050 and 21406034), Fundamental Research Funds for the central Universities (No. 3207045414). 


\section{References}

1. Dolbier, W. R., Jr.; Duan, J.-X.; Roche, A. J. Org. Lett. 2000, 2, 1867-1869. doi:10.1021/ol005943f

2. Dolbier, W. R., Jr.; Xie, P.; Zhang, L.; Xu, W.; Chang, Y.; Abboud, K. A. J. Org. Chem. 2008, 73, 2469-2472. doi:10.1021/jo7026849

3. Rossen, K.; Pye, P. J.; Maliakal, A.; Volante, R. P. J. Org. Chem. 1997, 62, 6462-6463. doi:10.1021/jo971300a

4. Hicks, C.; Duffy, B.; Hargaden, G. C. Org. Chem. Front. 2014, 1, 716-725. doi:10.1039/c4qo00110a

5. Morphy, J. R.; Rankovic, Z.; Rees, D. C. Tetrahedron Lett. 1996, 37, 3209-3212. doi:10.1016/0040-4039(96)00497-2

6. Seuron, P.; Solladie, G. J. Org. Chem. 1980, 45, 715-719. doi:10.1021/j001292a033

7. Amii, H.; Hayashi, R.; Seo, M.; Katahira, Y.; Kobayashi, A.; Uneyama, K. J. Fluorine Chem. 2013, 152, 90-93. doi:10.1016/j.jluchem.2013.04.001

8. Paradies, J. Synthesis 2011, 3749-3766. doi:10.1055/s-0031-1289296

9. Bartholomew, G. P.; Bazan, G. C. J. Am. Chem. Soc. 2002, 124, 5183-5196. doi:10.1021/ja0121383

10. Pravst, I.; Zupan, M.; Stavber, S. Green Chem. 2006, 8, 1001-1005. doi:10.1039/B608446J

11. Heropoulos, G. A.; Cravotto, G.; Screttas, C. G.; Steele, B. R. Tetrahedron Lett. 2007, 48, 3247-3250. doi:10.1016/j.tetlet.2007.03.023

12. Pravst, I.; Zupan, M.; Stavber, S. Tetrahedron 2008, 64, 5191-5199. doi:10.1016/j.tet.2008.03.048

13. Podgoršek, A.; Stavber, S.; Zupan, M.; Iskra, J. Green Chem. 2007, 9, 1212-1218. doi:10.1039/b707065a

14. Guha, S. K.; Wu, B.; Kim, B. S.; Baik, W.; Koo, S. Tetrahedron Lett. 2006, 47, 291-293. doi:10.1016/j.tetlet.2005.11.023

15. Podgoršek, A.; Stavber, S.; Zupan, M. Tetrahedron 2009, 65, 4429-4439. doi:10.1016/j.tet.2009.03.034

16. Podgoršek, A.; Stavber, S.; Zupan, M.; Iskra, J. Tetrahedron Lett. 2006, 47, 7245-7247. doi:10.1016/j.tetlet.2006.07.109

17. Chow, H.-F.; Low, K.-H.; Wong, K. Y. Synlett 2005, 2130-2134. doi:10.1055/s-2005-872270

18. Winberg, H. E.; Fawcett, F. S.; Mochel, W. E.; Theobald, C. W. J. Am. Chem. Soc. 1960, 82, 1428-1435. doi:10.1021/ja01491a037

19. Winberg, H. E.; Fawcett, F. S. Org. Synth., Coll. Vol. V; John Wiley and Sons, Ltd.: New York, 1973; pp 883-886.

20. Galley, R. A.; Landon, R. S.; Senior, K. C. [2.2]paracyclophane and derivatives thereof. U.S. Patent 5302767, April 12, 1994.

21. Dix, I.; Hopf, H.; Satyanarayana, T. B. N.; Ernst, L. Beilstein J. Org. Chem. 2010, 6, 932-937. doi:10.3762/bjoc.6.104

\section{License and Terms}

This is an Open Access article under the terms of the Creative Commons Attribution License

(http://creativecommons.org/licenses/by/4.0), which permits unrestricted use, distribution, and reproduction in any medium, provided the original work is properly cited.

The license is subject to the Beilstein Journal of Organic Chemistry terms and conditions:

(http://www.beilstein-journals.org/bjoc)

The definitive version of this article is the electronic one which can be found at:

$\underline{\text { doi: } 10.3762 / \text { bjoc. } 12.237}$ 